IZA DP No. 5913

Relative Cohort Size, Relative Income, and Women's Labor Force Participation 1968-2010

Diane J. Macunovich

August 2011 


\title{
Relative Cohort Size, Relative Income, and Women's Labor Force Participation 1968-2010
}

\author{
Diane J. Macunovich \\ University of Redlands \\ and IZA
}

\section{Discussion Paper No. 5913 \\ August 2011}

\author{
IZA \\ P.O. Box 7240 \\ 53072 Bonn \\ Germany \\ Phone: +49-228-3894-0 \\ Fax: +49-228-3894-180 \\ E-mail: iza@iza.org
}

Any opinions expressed here are those of the author(s) and not those of IZA. Research published in this series may include views on policy, but the institute itself takes no institutional policy positions.

The Institute for the Study of Labor (IZA) in Bonn is a local and virtual international research center and a place of communication between science, politics and business. IZA is an independent nonprofit organization supported by Deutsche Post Foundation. The center is associated with the University of Bonn and offers a stimulating research environment through its international network, workshops and conferences, data service, project support, research visits and doctoral program. IZA engages in (i) original and internationally competitive research in all fields of labor economics, (ii) development of policy concepts, and (iii) dissemination of research results and concepts to the interested public.

IZA Discussion Papers often represent preliminary work and are circulated to encourage discussion. Citation of such a paper should account for its provisional character. A revised version may be available directly from the author. 
IZA Discussion Paper No. 5913

August 2011

\section{ABSTRACT}

\section{Relative Cohort Size, Relative Income, and Women's Labor Force Participation 1968-2010}

Relative cohort size - the ratio of young to prime-age adults - and relative income - the income of young adults relative to their material aspirations, as instrumented using the income of older families their parents' age - have experienced dramatic changes over the past 40 years. Relative cohort size has been shown to cause a decline in men's relative wages - the wages of young relative to prime-age workers - due to imperfect substitutability, and the results here show that this applies perhaps even more strongly to women's relative and absolute - starting wage. Relative cohort size first declined by $30 \%$ and then increased by $47 \%$. Results here show that those changes explain about $60 \%$ of the declines in women's starting wage - both relative and absolute - in the first period, and $100 \%$ of its increase in the second. Relative income is hypothesized to affect a number of demographic choices by young adults, including marriage, fertility and female labor force participation, as young people strive to achieve their desired standard of living. Older family income - the denominator in a relative income variable - increased by $58.6 \%$ between 1968 and 2000, and then declined by $9 \%$. Its changes explain $66 \%$ of the increase in the labor force participation of women in their first five years out of school between 1968 and 2000, and 75\% of its decline thereafter. The study makes use of individual-level measures of labor force participation, with instrumented wages, and employs the lagged income of older families in a woman's year-state-race-education group to instrument parental income and hence material aspirations.

JEL Classification: J22

Keywords: relative cohort size, relative income, women's labor force participation, sex ratio, women's hours worked

Corresponding author:

Diane J. Macunovich

Department of Economics

University of Redlands

Redlands, CA 92346

USA

E-mail: diane_macunovich@redlands.edu 
Between 1968 and 1985, labor force participation (LFP) among married women 0-15 years out of school increased by $67 \%$ - but in the following fifteen years it increased by only $7 \%$, and then declined by $1 \%$ in the most recent decade. For all women 0-15 years out of school, the figures were $47 \%, 6 \%$ and $-2.3 \%$. Blau and Kahn (2007), in looking at the first two periods, found a strong rightward shift of the labor supply function in the first period, with a decrease in the own wage elasticity, but little change in the second period. Macunovich (2010), using the Blau and Kahn model, found the same pattern, but a subsequent leftward shift in the supply function in the most recent decade, and an increase in the own wage elasticity ${ }^{1}$. Neither of these studies attempted to explain the underlying causes of these shifts.

Juhn and Potter (2006) provided a comprehensive review of work looking at a number of different factors affecting women's LFP, both on the supply and demand sides. They cited Galor and Weil's (1996) support for demand-side factors in the 1980s and 1990s, with the move from manufacturing to the service sector and correlations with computer investment in Weinberg (2000). But they pointed out that this argument works less well for the 1970s, when the largest increases in women's LFP occurred, a conclusion supported by Quinlan and Shackelford (1980). On the supply side, Juhn and Potter cited work pointing to the effect of divorce, with the risk of divorce increasing LFP even among married women. Johnson and Skinner (1986) estimated that divorce rates might have accounted for about $17 \%$ of the observed increase in LFP for all women between 1960 and 1980.

Juhn and Potter also consider stagnating male wages as a possible factor in observed increases, but point out that increases in married women's labor supply occurred almost equally among women whose husbands were in the top and bottom income quintiles. And male wages - expected to have a negative effect on married women's LFP - have declined markedly since 2000, a period when female LFP also declined. In terms of own-wage effects, Pencavel (1998) found that very little of the change could be

\footnotetext{
${ }^{1}$ Both the Blau and Kahn and Macunovich articles looked at women aged 25-54, rather than at women by years out of school.
} 
attributed to observed wage differentials. Parkman (1992) and Rosen (1992) pointed out that during the 1970s wages actually declined during the period of the largest increases in women's labor supply. Similarly, Blau and Kahn (2007) pointed out that the stagnation of rates in the 1990s can't be attributed to wages since this was a period of rapid increases in the wage.

\section{Relative Cohort Size and Relative Income as Explanatory Factors}

Because of the inability of many of these other factors to explain the path of female labor force participation over the past 40 years, this study considers an alternative: changing relative cohort size and its resulting changes in relative income. Relative cohort size refers to the number of young adults relative to the number of prime-age adults, a ratio that increased by over 50\% between 1965 and 1980. Due to imperfect substitutability between inexperienced and experienced workers in the labor market, the wages of the younger workers in these large cohorts declined sharply relative to the wages of the older more experienced workers - their parents' cohort (Welch, 1979; Berger, 1984, 1985, 1989; Macunovich, 1999). This in turn caused a sharp decline in male relative income, which was defined by Richard Easterlin (1978) as the earning potential of young males relative to their aspirations, with their aspirations a function of the standard of living experienced in their parents' homes. When earning potential falls short of aspirations, various demographic adjustments are hypothesized to occur in order to maintain per capita income as high as possible: deferred or foregone marriage and children, and increased female labor force participation. Easterlin demonstrated that by making these adjustments - deferred or forgone marriage and childbearing, and increased female labor force participation - the baby boomers managed to achieve and even surpass their parents' standard of living (Easterlin, Macunovich and MacDonald, 1990). Macunovich (2011b) demonstrated the negative effect that increasing older family income has had on marriage rates among young adults, and Devaney (1983) and Macunovich (1996, 2011a) demonstrated its negative effects on childbearing. 
Relative cohort size might be expected to influence not just young men's relative wages, but young women's, as well. And in this sense relative cohort size would work through four different paths to affect women's labor force participation. The direct effect would be on the starting wage of young women, which can be expected to influence their LFP. Indirectly, through relative income, LFP would be affected by changes in marriage rates, fertility, and education. Reduced marriage rates - as young men forego marriage in an attempt to bolster per capita income - would leave more women needing to support themselves, and thus contemplating labor force entry. For women who do marry, relative income would affect fertility through a couple's attempts to maintain a higher per capita income, and this reduced fertility would free women for increased LFP. And finally, in anticipation of participation in the labor market, women would increase their level of education in order to command a higher wage and, since labor force participation is higher at higher levels of education, labor force participation rates would increase.

Easterlin's measure of male relative income declined sharply in the 1970s and early 1980s, during the period when relative cohort size and female labor force participation experienced their sharpest increases (see Figure 1 on the left). However, male relative income did not rebound subsequently, when relative cohort size began to decline, because of older married women's increasing labor force participation. This is seen in Figure 1 on the right, in the comparison of older family income (the denominator in male relative income) with the average income of older fathers. Between 1968 and 2010, older families' income increased by $44.6 \%$ while fathers' income increased by only $12.7 \%$. Thus we cannot expect symmetry in the effects of relative cohort size on either male relative income or on young women's LFP, due to the effect of increasing LFP among older women. The hypothesis here then is that relative income, the proximate cause, not relative cohort size, the direct cause, should be explored as having the most obvious effect on young women's LFP and hours worked. This relative income concept was tested and found to be highly significant in terms of fertility and female labor force participation, by Devaney (1983) and 
Macunovich (1996) - but both of those studies consisted of simple time series analyses, with the associated limitations, especially in terms of number of observations.

This study uses individual-level data on labor force participation and hours worked by women in the period 1968-2010, and relates those variables to own and male wages and the income of families with head aged 45-54 in related year-state-race-education groupings - a measure of the denominator in relative income. This methodology permits the exploitation of cross-section variation in the family income variable not available in simple time series analyses. It is expected that the older family income will exert a positive effect on women's labor force participation and hours, as individuals strive to achieve their desired standard of living.

The use of family income at the year-state-race-education level can be thought of as an instrument for a woman's own family's income, which is necessary to abstract from the more commonly accepted role of family income in a woman's labor force participation. That is, family income is closely correlated with parents' level of education, which in turn is correlated with their children's achieved education, which in turn is correlated with a woman's labor force participation. In addition, family income is highly correlated with the mother's labor force participation, which can be highly correlated with her daughter's participation through a role model effect. Thus in order to approximate just the role of family income in forming a woman's material aspirations, it is necessary to use an instrument which can be thought of as indicating the general level of affluence in her associated social group. This of course also gets around the problem that it is rare in a data set to find data on a young adult's parental income at the time the young adult was living at home.

\section{Relative Cohort Size and Women's Relative Starting Wage}

Obviously the starting wage - the wage women face when first contemplating labor force entry - should be an important factor in women's labor force participation. To what extent has it been affected by 
changing relative cohort size - the number of young relative to prime-age adults? A strong negative effect of relative cohort size on young men's wage relative to that of older more experienced workers, due to imperfect substitutability, has been demonstrated many times over the past decades (Welch 1979; Berger 1984, 1985, 1989; Macunovich 1999). But little attention has been given to women's wages. It is not really feasible to examine younger women's wage relative to that of older women, because of the sometimes sporadic labor force participation of women. Instead, here, the relationship is examined with respect to the wage of older experienced males. What might be the mechanism for such an effect on women's wages? Certainly, as with young men, there would be imperfect substitutability between young women and older experienced male workers - complementarity, even, in earlier periods when occupational segregation was highest. And if in fact, as hypothesized here, women entered the labor force in the 1970s at least in part in response to falling male relative wages - which have been shown to have been a function of changing relative cohort size - then their own resulting increased participation rates would have compounded the effects of increasing female cohort size. In that case, then, relative cohort size would have worked on women's relative wage through two different channels.

Thus, in addition to determining the effect of relative income on women's LFP and hours worked analyses in which a woman's own (imputed) wage is used - a further analysis is conducted here to attempt to determine the role of relative cohort size on women's relative wage. Only women's starting wage is used in the latter analysis (the hourly wage in the first year out of school, in 2009 dollars, of women who are no longer enrolled in school, specific to given year-state-race-education groups) because of the potential endogeneity of women's wages due to their sometimes sporadic labor force participation. This starting wage is used in a ratio with the hourly wage of men with 25-34 years of work experience, in the same year-state-race-education groupings. Relative cohort size is instrumented - again, because of potential endogeneity, with individuals migrating to areas with better wages - using a 25-year lag of the General Fertility Rate (GFR) as in Macunovich (1999). The GFR is used because it represents the number of births to women of childbearing age, which, 25 years later, would be a close approximation to the 
number of young relative to prime-age adults. Historic trends in women's relative starting wage, by education level, are presented in Figure 2, together with an inverted lagged GFR. It can be seen that there is a close correspondence between these curves, especially for women with lower levels of education even in terms of the stagnation or decline since 2000.

\section{The Response to Changing Sex Ratios}

A concept closely related to that of relative income and relative cohort size, is that of sex ratios - the ratio of males to females. When cohort size changes as dramatically as it has in the U.S. over the last 40 years, it induces changes in the ratio of marriage-eligible males to females, because of the traditional two-year difference in age between the genders. When cohort size is increasing, as it was in the 1970s, the older cohorts are smaller than the younger, leading to a lower sex ratio - and conversely in the late 1980s and into the 1990s older cohorts were larger than younger, leading to higher sex ratios. Grossbard and Amuedo-Dorantes (2006) tested the hypothesis that there would be a negative relationship between the sex ratio and female labor force participation, with more women entering the labor market when the chances of marriage are low. Their study found a negative relationship, with large cohorts significantly more likely to enter the labor force - but that is hard to square with the time series evidence, as shown in Figures 2 - 5.

\section{A Look at the Data}

Figures 2 - 4 illustrate historic patterns of female labor force participation and hours worked in the study period - Figure 2 for married women, Figure 3 for unmarried women, ${ }^{2}$ and Figure 4 for all women. It is important to look at the pattern for all women separate from those of married and unmarried, because reduced marriage rates leave more women in a group with traditionally higher labor force participation rates. The graphs on the left in each figure illustrate patterns by years out of school, while those on the

\footnotetext{
${ }^{2}$ Married women are those with a spouse present only. The unmarried category includes all other women, regardless of marital status.
} 
right illustrate patterns by years of education. In the "years out of school" graphs we can see the marked increases in LFP and hours that occurred between 1968 and 2000, with stagnation or even decline thereafter. This is striking as an inverse of the pattern of male relative income shown in Figure 1. Looking at the "years of education" graphs the increase is not as marked ${ }^{3}$ : it is obvious that a portion of the observed increases is attributable to an overall increase in the level of education. This is not surprising, in a relative income context, since women contemplating entering the labor force in order to achieve a desired standard of living can be expected to increase their education in anticipation of that participation.

However, Figure 5 illustrates the historic pattern of two different sex ratios. Both ratios assume a twoyear difference in age between the men and the women, consistent with observed ages at marriage. On the left are time-varying sex ratios for three age groups - women aged 15-24, 25-29 and 30-34. These ratios assume that a woman will experience different sex ratios throughout her life - that is, that even once married she will be affected by the current age-specific sex ratio due to the prevalence of high divorce rates. On the right is a cohort-specific sex ratio: the ratio that each birth cohort would have experienced when aged 20-24. Grossbard and Amuedo-Dorantes (2006) used a cohort-specific rate in their analyses. But the striking feature of all of these sex ratios is the similarity in pattern between the sex ratios, and the patterns of labor force participation in Figures 2 - 4, with strong increases in the first part of the time period, followed by stagnation or decline. The relationship would appear to be positive, rather than negative, as found by Grossbard and Amuedo-Dorantes. This will be tested in subsequent analyses.

\section{Data and Methodology}

The data used for the analysis are taken from the March Current Population Survey (CPS) as made uniform by Unicon's "CPS Utilities". The years covered are 1968-2010 (1966-2010 for older family

\footnotetext{
${ }^{3}$ But note that there is a difference in scale because of the low levels of participation among those with less than twelve years of education.
} 
income, in order to use a two-year lag for the youngest women). Only women in the first fifteen years out of school were included in the analysis, since this is expected to cover the groups most likely to be affected by earlier parental standards of living. Husbands were matched to wives in the married sample using the hierarchical structure of the CPS. Further details on data development are provided in the Data Appendix.

The models estimated - separately for 0-15, 0-5, 6-10 and 11-15 years out of school, and for single, married and all women - were

$$
\begin{aligned}
& H_{i}=\beta_{0}+\beta_{1} \ln F_{t s r e}+\beta_{2} \ln W f_{i}+\beta_{3} t \ln W f_{i}+\beta_{4} \ln W h_{i}+S R_{t s a}+\mathrm{B}^{\prime} X+u_{i} \\
& \left(\text { Prob Inlf } f_{i}=1\right)=\beta_{0}+\beta_{1} \ln F_{t s r e}+\beta_{2} \ln W f_{i}+\beta_{3} t \ln W f_{i}+\beta_{4} \ln W h_{i}+S R_{t s a}+\mathrm{B}^{\prime} X+u_{i}
\end{aligned}
$$

Where

$H_{i} \quad$ is annual hours worked by an individual $i$ (including those with zeroes);

Inlf $_{i}$ is a dichotomous variable indicating a woman's labor force status;

$F_{\text {tsre }}$ is older family income specific to a woman's year-state ${ }^{4}$-race-education group. It is lagged two years for those 0-5 years out of school, seven years for those 6-10 years out of school, and twelve years for those 11-15 year out of school, to approximate the time when the individual was still living in her parents' home;

$W f_{i} \quad$ is the woman's own (imputed and instrumented) wage;

$W h_{i} \quad$ is the husband's (imputed and instrumented) wage, for married women;

$t \ln W f_{i}$ is an interaction term between the woman's own logwage and time;

$S R_{t s a}$ is the year-state-age-specific sex ratio, the ratio of males to females two years younger; and

$X \quad$ is a vector of control variables.

The control variables included four education dummies and two race dummies - for wife and husband in the married women's equation, and for the woman only in the single and all women's equations - a time trend, twenty state dummies, an appropriate number of "years out of school" dummies, and two indicators of MSA status. Also included in the married women's control variables were number of children under 6, and number of children aged 6-17. For single women the husband's wage was replaced with the average

\footnotetext{
${ }^{4}$ Although only 21 state groupings are common across all years in the CPS, in defining the year-state-race-education cells more detailed year-by-year state groupings are used: 30 groups in the 1968-72 period, 23 in the 1973-76 period, and 51 from 1977 onward (including the District of Columbia).
} 
expected logwage ${ }^{5}$ of men two years older than the woman, in her specific year-state-race-education group. Equation (1) was estimated as a linear IV equation, while equation (2) was estimated as an IV probit.

In addition, two other models were estimated, for the female starting wage and its relative version:

$$
\begin{aligned}
& W f_{\text {tsre }}=\beta_{0}+\beta_{1} G F R_{t-25}+B_{2}{ }^{\prime} S+B_{3}{ }^{\prime} R+B_{4}{ }^{\prime} E+\beta_{5} \text { time }+u \\
& \text { relWf } f_{\text {tsre }}=\beta_{0}+\beta_{1} G F R_{t-25}+B_{2}{ }^{\prime} S+B_{3}{ }^{\prime} R+B_{4}{ }^{\prime} E+\beta_{5} t i m e+u
\end{aligned}
$$

where

$W f_{\text {tsre }}$ is the year-state-race-education-specific real hourly wage of women in their first year out of school;

relWf $t_{\text {tsre }}$ is the year-state-race-education-specific real hourly wage of women in their first year out of school, relative to the real hourly wage of men with 25-34 years of work experience, in the same year-state-race-education categories - the female relative starting wage;

$G F R_{t-25}$ is a 25-year lag of the U.S. General Fertility Rate (births per 1000 women of child-bearing age);

$S \quad$ is a vector of dummies for the 21 state groupings that are common over all years in the CPS;

$R \quad$ is a vector of dummies for three racial groups: White, African American and Other;

$E \quad$ is a vector of dummies for six educational categories: $<8,8-11,12,13-15,16$ and $>16$ years;

time is a time trend.

The methodology for determining own wages - for all women and for husbands in the married sample comprised three steps, following on Blau and Kahn (2007). In the first, hourly wages were calculated - in 2009 dollars - using the procedure outlined in the Data Appendix. The hourly wage was imputed for those with no reported wage, the self-employed, and those whose calculated wage fell outside the range $\$ 2.50$ - \$250 in 2009 dollars. The imputation process was based on separate logwage regressions - in five-year groupings - for those with less than 20 weeks worked and those with 20 or more weeks worked, separately for men, married women, and single women. That is, it was assumed that wages should be imputed based on the reported wage of those in groups with similar numbers of weeks worked. The

\footnotetext{
${ }^{5}$ The expected logwage is the average logwage multiplied by the employment rate (1-unemployment rate) in the men's year-state-race-education-experience group.
} 
regressions included age and age squared, together with four year dummies, four education dummies, two race dummies, twenty state dummies, and indicators for central city and other MSA.

In the second step, treating own and spouse wages as endogenous, wages were instrumented by regressing logwage on age and age squared, four education dummies, two race dummies, twenty state dummies and two indicators for MSA status. In addition, following on Blau and Kahn (2007) and Macunovich (2010), a series of dummy variables representing wage deciles was included, which served as excluded instruments in the final hours and labor force status equations. As indicated in Blau and Kahn, use of the deciles "corrects to some degree for measurement error in the wage" (p. 406). These regressions, too, were estimated in five-year groupings, and separately for married women, single women, and men.

The third step involved estimating the equations in (1) as weighted IV linear models using Stata's robust regression, and equations in (2) as weighted IV probits using Stata's dprobit, with results presented for all women in Table 1, married women in Table 2, and single women in Table 3. The result of estimating equations (3) and (4), using Stata's robust regression, are presented in Table 4.

\section{Regression Results for Annual Hours Worked}

These results for equation (1) are presented in the first four columns of Tables $1-3$. The coefficient on logged family income - the assumed denominator in a relative income variable - is positive and highly significant for all women except for single women 6-10 years out of school (Table 3). The higher the desired standard of living, the more intensively a woman participates in the labor market. It is notable that even married women 6-15 years out of school are still affected by older family income experienced 7-12 years earlier. The coefficients suggest that the 58.6\% increase in older family income that occurred between 1968 and 2000 would have been responsible, among women 0-5 years out of school, for 24\% of the overall increase in hours worked that occurred during this period. For married women, changes in 
older family income explain 13\% of the observed increase, while for single women those changes account for $28 \%$ of the observed increase. Similar proportions apply in the period after 2000, when older family income and annual hours both decreased. It is important to remember that older family income here is instrumented in order to avoid as much as possible the obvious effect that a woman's own family income might have on her level of LFP, both through achieved education level and (mother's) example. Here, older family income is the general level of affluence in her year-state-race-education group, rather than in her own home.

The coefficient on the male wage - the numerator in a relative income variable - is negative and highly significant, as expected, over all (Table 1) and for married women (Table 2). But for single women (Table 3) it is significant only for women 0-5 years out of school - but with a positive sign. (It is significant for women 0-15 years out, as well - but this is most likely simply because of the inclusion of the 0-5 group.)

The coefficient on the time/age varying sex ratio is highly significant, for all women and for all "years out of school" groups - but unlike the results presented in Grossbard and Amuedo-Dorantes (2006), all coefficients here display a positive sign. It is difficult to interpret this result, but it is similar to findings in Angrist (2002) and Macunovich (2011b). The theory is that more women will enter the labor force when marriage prospects are lower - that is, when the sex ratio is low - but the results here suggest that the opposite is true. The theory might have held in the early 1970s, when women's LFP increased sharply at the same time that increasing cohort size drove down the sex ratio. But since the 1980s the sex ratio has been very high, at the same time that women's LFP is also very high. Grossbard and Amuedo-Dorantes's Table 1 relates their sex ratio to the period change in LFP, rather than to the level - a relationship that certainly holds as women's LFP leveled out asymptotically. Regressions not presented here, using a cohort-level sex ratio like theirs (that is, one that remains constant for a woman over the life cycle), produced similar highly significant positive results. 
The results for the female wage are consistent with the findings in Blau and Kahn (2007) and Macunovich (2010): coefficients are positive and highly significant in all cases, across the board, but the coefficients on the wage's interaction with time are all negative and statistically significant. The combination suggests a positive elasticity that will reach zero sometime after the middle of this century, at the earliest.

In terms of the control variables, there is a significant positive time trend across the board, as one might expect, and hours worked increase for all groups as education level increases, also as one would expect although there is some indication of a dilution of that effect for married women 11-15 years out of school. That would be consistent with the observed trend since 2000, among older more educated women, to reduce hours or even drop out of the labor force (Belkin, 2003; Wallis, 2004). However, there is a significant contrast among all married women, between the effects of own education and effects of husband's education. Hours worked increase with levels of own education, but decrease with levels of husband's education (Table 2, highlighted). The other significant reversal occurs on the categorical variable for African Americans. The coefficients are all significant and negative for single women, but positive and significant (for own and husband) for married women. The coefficients for other non-white races are negative except among women 11-15 years out of school, where they are positive and significant.

\section{Regression Results for Labor Force Participation (LFP)}

These IV probit results are presented, with estimated marginal effects, in the last four columns in Tables 1-3. Here again, the coefficients on logged older family income are positive and highly significant for all groups except single women 6-15 years out of school. Here again, it is notable that married women even 6-15 years out of school are still responsive to older family income from the time when they were in their parents' homes. And again it is necessary to point out that this is an instrumented older family income, not the income experienced in a woman's own home, which might be expected to influence her LFP through effects on achieved education and (mother's) example. Here the older family income is simply 
that experienced in society around her, at the year-state-race-education level, that appears to have influenced her desired standard of living. The coefficients on older family income indicate that its 58.6\% increase between 1968 and 2000 would have been responsible for 66\% of the overall increase in LFP among women $0-5$ years out of school, $29 \%$ of the increase among married women $0-5$ years out of school, and $100 \%$ of the increase among single women 0-5 years out of school. In the period since 2000, older family income would have explained $75 \%$ of the $4 \%$ decline in participation for all women, $78 \%$ of the $3 \%$ for married women, and $24 \%$ of the $5 \%$ for single women.

The logged male wage has a negative effect only on married women (Table 2), where it is actually her husband's own instrumented wage. For single women it is the expected wage of males two years older than herself in her year-state-race-education group. There, among single women, the effect is not statistically significant (Table 3). The effect on married women does show up in the regression for all women, however, where again the effect is significant and negative (Table 1). (In those regressions, all women were assigned their respective year-state-race-education-age specific male expected wage.)

And once again, as for hours worked, the coefficient on the sex ratio is positive and highly significant. It is very difficult to explain what might be causing this positive sign (apart from the marked similarity in time trends, as seen in the Figures presented earlier). It certainly does not mesh with the theory. And here again, in results not presented here, the Grossbard and Amuedo-Dorante (2006) type of cohort-level variable produced similar positive and significant coefficients. To reiterate, the age-varying sex ratio is presented here since it is felt to be a superior measure given the high propensity to divorce, which would expose women to varying sex ratios over their lifetime.

The female wage once again, as for annual hours worked, displays a highly significant positive coefficient across the board - but again with a highly significant negative time trend, as well. As with hours worked, however, the size of the coefficient on the time trend does not indicate a turn to a negative overall 
coefficient until after the turn of the century, in most cases. But this negative trend is consistent with the findings in Blau and Kahn (2007) and Macunovich (2010).

In terms of the other control variables, there is across the board a strong positive effect of education, consistent with the graphs presented earlier. There is, however - as with hours worked - some indication of a dilution of that effect for married women 11-15 years out of school, where some of the signs become reversed. But here again, as with hours worked, the effect of husband's education for married women is reversed, with participation decreasing with husband's education (Table 2). There is a positive time trend, perhaps reflecting the general change in attitude toward women - especially married women - in the labor force. This trend is highly significant for all except single women 0-5 years out of school, where it is positive but not statistically significant (Table 3). And as with hours worked, the coefficient on the categorical variable representing African Americans is positive for married women but negative for single women - except for those further out of school.

\section{Regression Results for Women's Starting Wage}

The results of estimating equations (3) and (4) using Stata's robust regression are presented in Table 4. The coefficient on the lagged GFR is negative and highly significant, as hypothesized, both for the starting wage itself, and also for its ratio relative to the wage of men with 25-34 years of work experience. The estimated elasticity of the starting wage to changes in the lagged GFR is -0.28 , so that the $30 \%$ increase in the lagged GFR between 1968 and 1982 would have accounted for $60 \%$ of the $14.1 \%$ decrease in the starting wage during this period. The lagged GFR's decline by 47\% in the period between 1982 and 2001 accounted for $97 \%$ of the wage's $13.6 \%$ increase during that period.

The estimated elasticity of the relative starting wage with respect to the lagged GFR is -0.56 , so that the 30\% increase in the lagged GFR between 1968 and 1982 would have accounted for $62 \%$ of the $27 \%$ decrease in the female relative starting wage during this period. The lagged GFR's $47 \%$ decline from 
1982 to 2001 would have accounted for $100 \%$ of the $24 \%$ increase in the relative starting wage during that period.

\section{Conclusions}

There have been many factors - and combinations of factors - put forward to explain the dramatic changes that have occurred in women's labor force participation since the 1960s: changes in wages, changes in demand, and changes in divorce and fertility, among others. But a great deal of the change remains to be explained. This study has examined one more set of factors that have previously been explored only using time series data: relative cohort size and relative income (Devaney, 1983; Macunovich, 1996). The rationale for studying the effect of these factors goes back to Richard Easterlin (1978), who suggested that changes in relative cohort size produce, through imperfect substitutability in the labor market, changes in relative income - the income of young adults relative to their aspirations which in turn affect a host of demographic variables including marriage, fertility and female labor force participation. Young adults make these demographic changes in order to maintain a desired standard of living, determined at least in part by the standard of living enjoyed in their parents' home.

As a result, this study has looked at the effect of relative cohort size on women's wages, and relative income on women's labor force participation and hours worked. No attempt was made to test the effect of relative cohort size directly on women's labor market activity because it has been determined that trends in the intervening proximate cause - relative income - have diverged from trends in relative cohort size due to the increasing labor force participation of older women. Relative cohort size is expected to directly affect relative wages - the wages of young workers relative to those of prime-aged workers, which up until the mid-1980s largely determined the level of older family income. Older family income - the assumed denominator in a relative income variable - has trended up sharply over the study period due to the increase in two-earner households, while the income of older males has remained virtually unchanged, so that while relative wages have recovered after the baby boom, relative income has not. 
The analysis has been conducted at the micro level, using a two-step process to impute wages for those not reporting one (and for the husbands of married women), and then to instrument those wages due to their potential endogeneity. But older family income has not been used at the individual level, due to the many roles it plays in a young woman's labor force participation. It affects her not just through its effect on her material aspirations, but also through the observed correlation between parents' and children's education, and the effect of a mother's participation on that of her daughter. As a result, in order to abstract from the latter two effects, this study has used older family income - of families with head of either sex aged 45-54 - at the year-state-race-education level, to approximate the general level of affluence experienced by a young woman when she was growing up.

The study looks at all women in their first fifteen years out of school, separately for married and single women, as well as for all women over all. It is necessary to look at all women taken together, because of the slippage that occurs between the married and single state due to changes in relative income (Macunovich 2011b). When women move from the married to the single state they move to a group with a higher overall labor force participation.

Instead of testing relative income as a single variable - young men's wage relative to older family income - this study has entered the male wage and older family income as separate variables, under the assumption first, that the coefficients should not be constrained to be equal and second, that the comparison between older family income and the female wage might be significant, as well. All three have been used in logged form, and the estimated effect of the male wage is significantly negative and the effect of the female wage is significantly positive, as expected. What is notable in this study is that the coefficient on older family income is positive and highly significant for all but single women 6-15 years out of school. Among women 0-5 years out of school, its increase by 58.6\% between 1968 and 2000 would have been responsible for $24 \%$ of the overall increase in hours worked that occurred during this 
period. For married women, changes in older family income explain $13 \%$ of the observed increase, while for single women those changes account for $28 \%$ of the observed increase. Similar proportions apply in the period after 2000, when older family income and annual hours both decreased.

In terms of labor force participation, the 58.6\% increase in older family income between 1968 and 2000 would have accounted for $66 \%$ of the overall increase in LFP among all women 0-5 years out of school, $29 \%$ of the increase among married women $0-5$ years out of school, and $100 \%$ of the increase among single women 0-5 years out of school during that period. In the period since 2000, older family income would have explained $75 \%$ of the $4 \%$ decline in participation for all women, $78 \%$ of the $3 \%$ for married women, and $24 \%$ of the $5 \%$ for single women.

In addition to its indirect effects on hours worked and labor force participation, through relative income, relative cohort size has had a highly significant direct effect on women's absolute starting wage as well as their relative starting wage. That's the wage of unenrolled women in their first year out of school, relative to the wage of men with 25-34 years of work experience. Only the starting wage has been considered in this analysis, because of the potential endogeneity of wages later in life due to sporadic labor force participation. Relative cohort size has been instrumented here with a 25-year lag of the General Fertility Rate, due to potential endogeneity of state-level relative cohort size. The estimated elasticity of the absolute starting wage with respect to changes in relative cohort size is -0.28 , while the elasticity of the relative wage is -0.56 . As a result, the 30\% increase in the lagged GFR between 1968 and 1982 would have accounted for $60-62 \%$ of the decrease in both the absolute and relative starting wages during this period. The lagged GFR's 47\% decline from 1982 to 2001 would have accounted for $97-100 \%$ of the increase in the absolute and relative starting wages during that second period.

A measure of the sex ratio - the ratio of males to females in a given age group, with males two years older - was tested given that Grossbard and Amuedo-Dorantes (2007) found a significant negative effect 
on women's labor force participation. The hypothesis is that women tend to enter the labor force when marriage prospects are low. Two different forms of the variable were tested, one that is fixed for a woman at the level experienced when she was 20-24, and another that varies by age given that high divorce rates expose a woman to a constantly varying level, and both were found to exert a significant positive effect on women's labor force participation and hours worked. This makes sense given that the historic trends in the sex ratio follow closely the trends in these two variables, but does not support the hypothesis.

The results presented here, with respect to the effect of relative income on women's LFP, corroborate those of Devaney (1983) and Macunovich (1996), but strengthen those results because of the use of individual-level data instead of time series, and the inclusion of later years. They indicate that relative cohort size and relative income have been very significant factors in the observed changes that have occurred in women's labor force participation and hours worked since the 1960s. In addition, these results suggest that unless older family income recovers from the slump that it has been in since 2000, women's labor force participation will remain at its current level, or decline further, along with older family income. This is doubly true given the pattern of relative cohort size, which will be relatively flat through 2030, apart from a brief spike between now and 2022 - but that spike represents an increase of only $9 \%$, compared with the 30\% rise that occurred between 1968 and 1982. Thus there will be little overall increase in women's absolute and relative starting wage through at least 2030, based on the results here. Thus women's labor force participation cannot be expected to change substantially unless older family income changes in future, since there will be little change in the starting wage. 


\section{Bibliography}

Angrist, J (2002). How Do Sex Ratios Affect Marriage and Labor Markets? Evidence from America's Second Generation, The Quarterly Journal of Economics 117(3): 997-1038.

Belkin, Lisa (2003). "The opt-out revolution", New York Times Magazine, October 26, 2003.

Berger M (1984) Cohort Size and the Earnings Growth of Young Workers. Industrial and Labor Relations Review 37(4):582-591.

Berger M (1985) The Effect of Cohort Size on Earnings Growth: a Re-examination of the Evidence. Journal of Political Economy 93:561-573.

Berger M (1989) Demographic Cycles, Cohort Size, and Earnings. Demography 26(2):311-321.

Blau, Francine and L.M.Kahn (2007). "Changes in labor supply behavior of married women 1980-2000", Journal of Labor Economics, 25(31):393-438.

Devaney, B (1983). An Analysis of Variations in U. S. Fertility and Female Labor Force Participation Trends, Demography 20(2):147-161.

Easterlin, RA (1978). What Will 1984 Be Like? Socioeconomic Implications of Recent Twists in Age Structure@, Demography, 15(4 Nov): 397-432.

Easterlin, RA, DJ Macunovich and C MacDonald (1990). How Have the American Baby Boomers Fared? Earnings and Economic Well-Being of Young Adults, 1964-1987, Journal of Population Economics, 3(4):277-290.

Galor, O and DN Weil (1996). The Gender Gap, Fertility and Growth, American Economic Review 86(3):374-387.

Grossbard, S and C Amuedo-Dorantes (2006). Cohort-level Sex Ratio Effects on Women's Labor Force Participation, Review of Economics of the Household 5(3): 249-278.

Jaeger, David A. (1997). "Reconciling educational attainment questions in the CPS and the Census", Monthly Labor Review, August, pp.36-40.

Juhn, C and S Potter (2006). Changes in Labor Force Participation in the United States, Journal of Economic Perspectives, 20(3):27-46.

Macunovich, DJ (1996). Relative Income and Price of Time: Exploring Their Effects on US Fertility and Female Labor Force Participation, Population and Development Review, 22(supplement):223257.

Macunovich, DJ (2010). Reversals in the Patterns of Women's Labor Supply in the U.S., 1976-2009, Monthly Labor Review, November: 16-36.

Macunovich, DJ (2011a). Re-visiting the Easterlin Hypothesis: U.S. Fertility 1968-2010, IZA DP\#5885. 
Macunovich, DJ (2011b). Re-visiting the Easterlin Hypothesis: Marriage in the U.S. 1968-2010, IZA DP\#5886.

Parkman, AM (1992). Unilateral Divorce and the Labor-Force Participation Rate of Married Women, Revisited, American Economic Review 82(3):671-678.

Pencavel, JH (1998). The Market Work Behavior and Wages of Women: 1975-94, Journal of Human Resources 33(4):771-804.

Quinlan, DC and JA Shackelford (1980). Labor Force Participation Rates of Women and the Rise of the Two-Earner Family, American Economic Review 70(2):209-212.

Rosen, S (1992). Mincering Labor Economics, Journal of Economic Perspectives, 6:157-170.

U.S. Department of Commerce, Bureau of the Census (2010). "Current Population Survey, March Supplement", as prepared by the Unicon Corporation in CPS Utilities.

Wallis, Claudia (2004). "The Case for Staying Home", Time, May 10, 2004.

Weinberg, B (2000). Computer Use and the Demand for Female Workers, Industrial and Labor Relations Review 53(2):290-307.

Welch F (1979) Effects of Cohort Size on Earnings: the Baby Boom Babies' Financial Bust. Journal of Political Economy 87(5,pt.2):S65. 
Figure 1: Male Relative Income and a Comparison of Older Fathers' Income with Older Family Income $^{6}$.
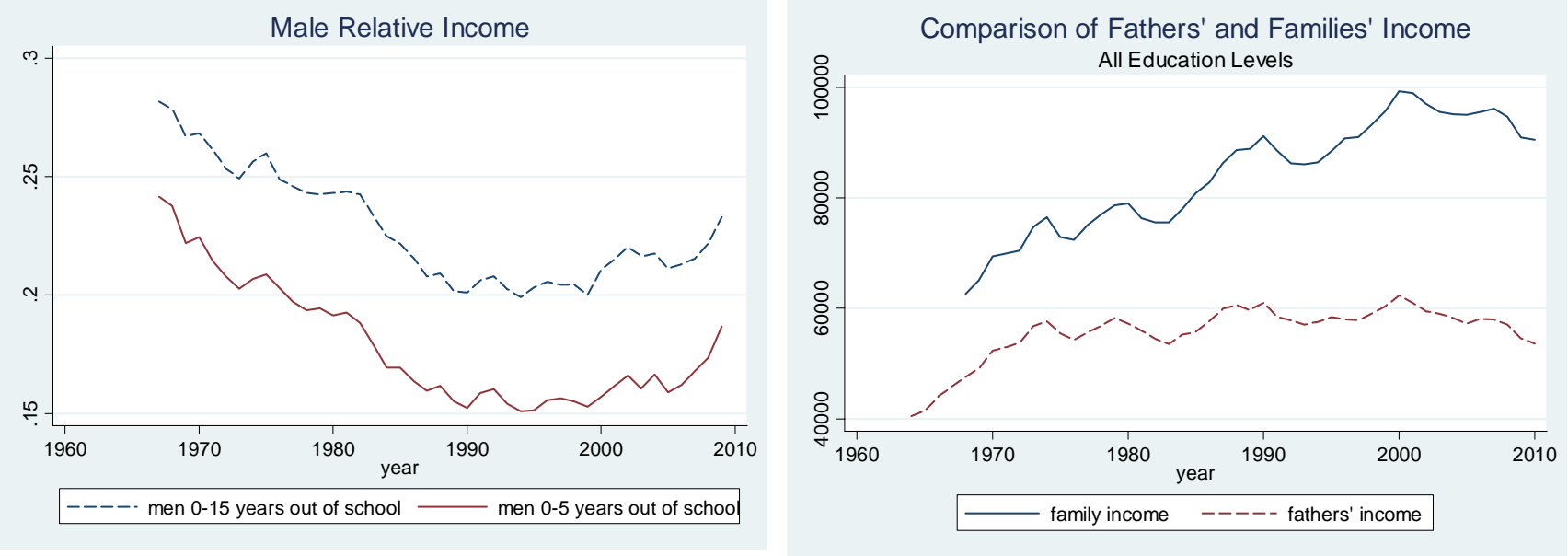

${ }^{6}$ Older fathers' income is the average income of male family heads aged 45-54, whereas older family income is the income of families with head of either sex aged 45-54. 
Figure 2: Women's Relative Wage - the Starting Wage Relative to the Wage of Men with 25-34 Years of Work Experience, with the Same Level of Education, Compared with a Measure of Relative Cohort Size
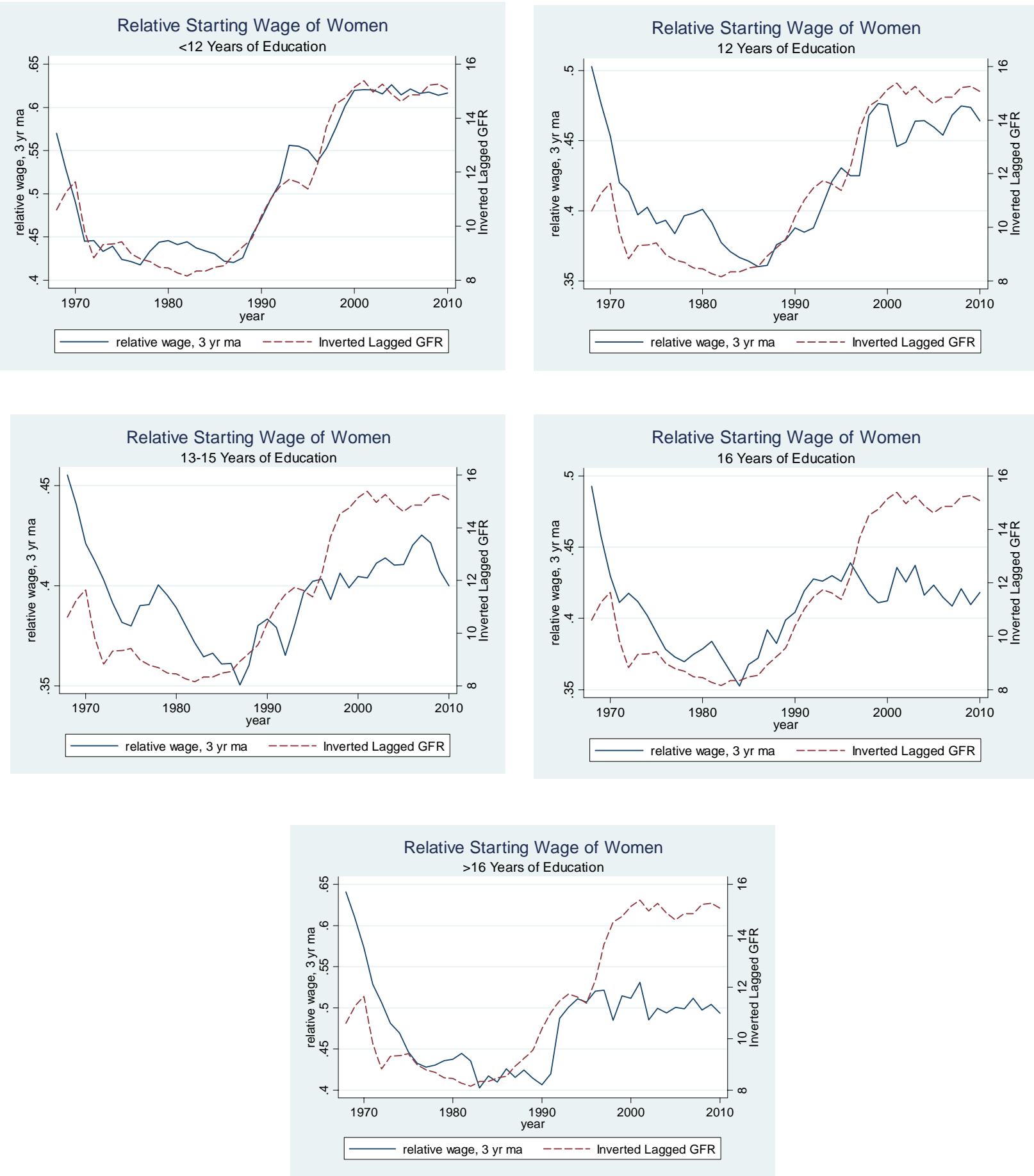


\section{Figure 3: Labor Force Participation and Hours Worked by Married Women}
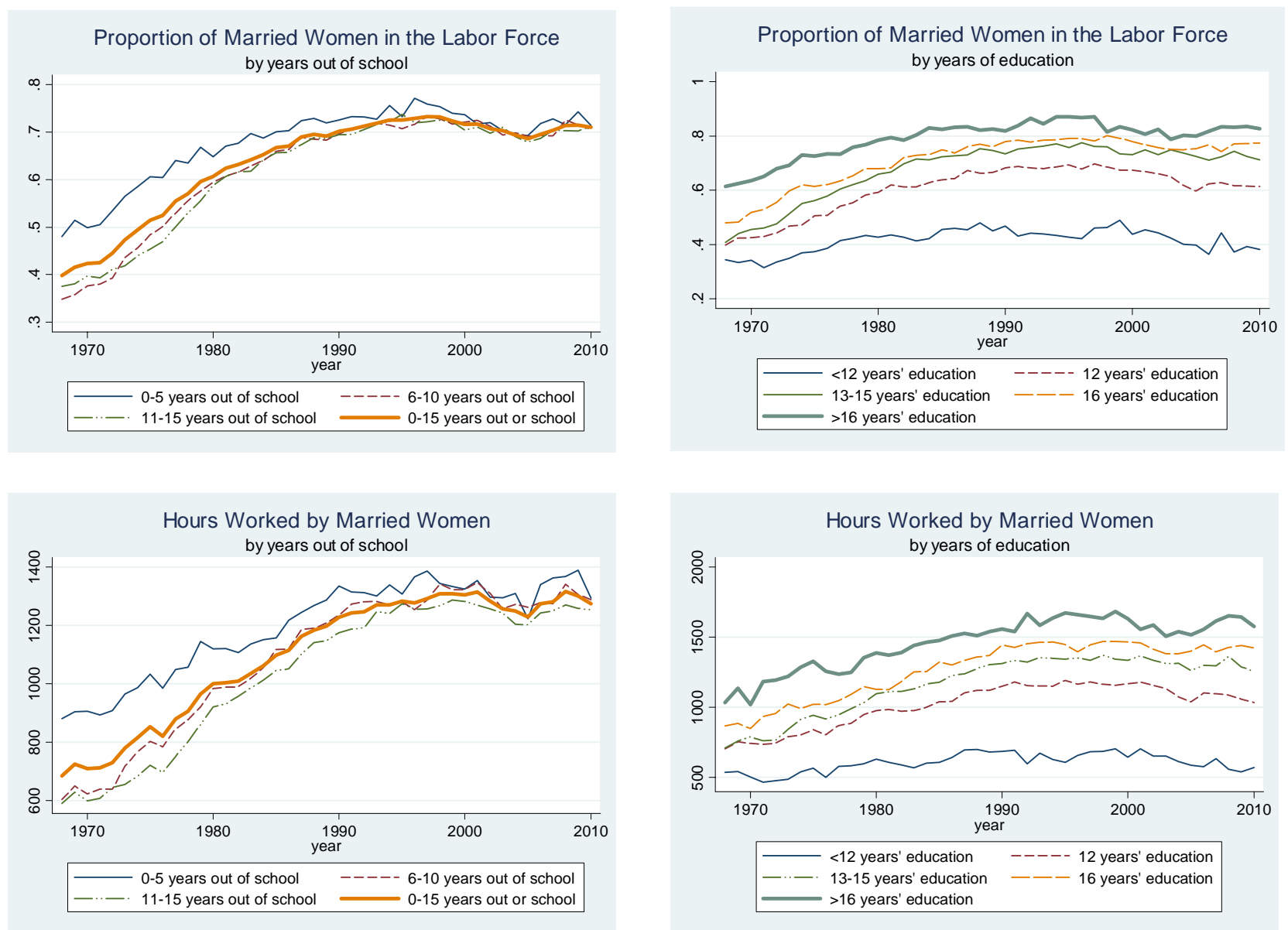
Figure 4: Labor Force Participation and Hours Worked by Unmarried Women
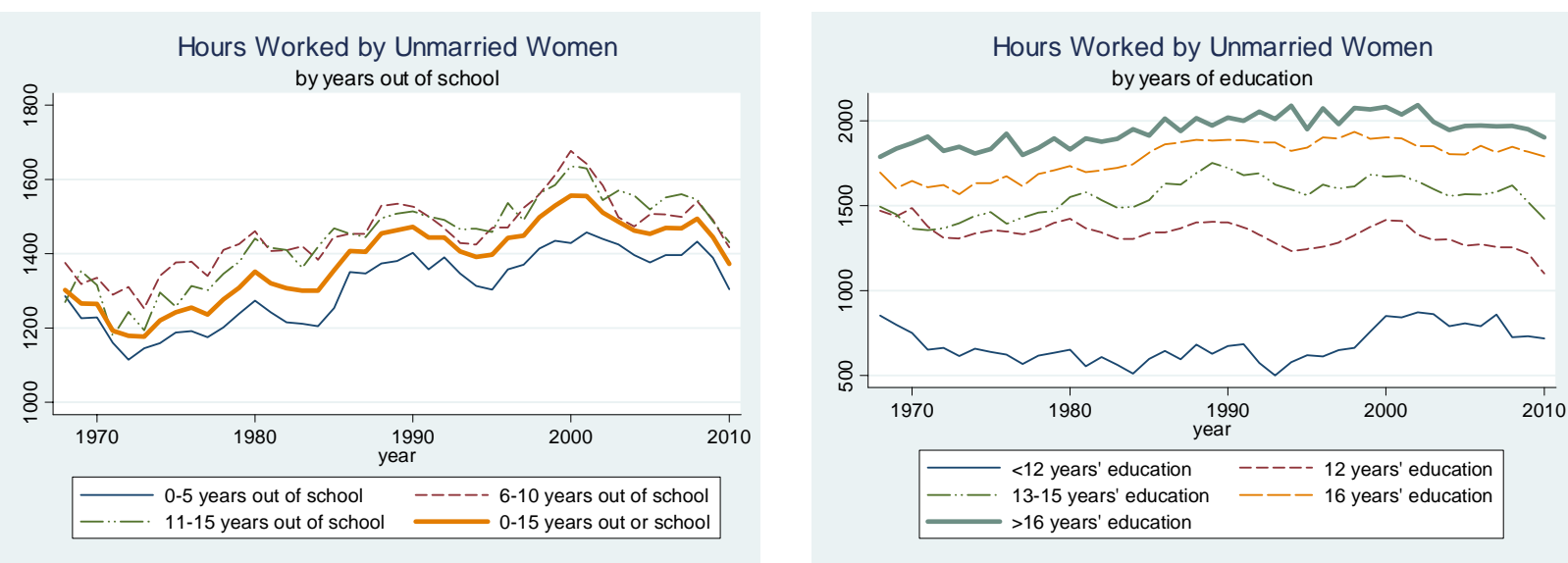

Proportion of Unmarried Women in the Labor Force by years out of school

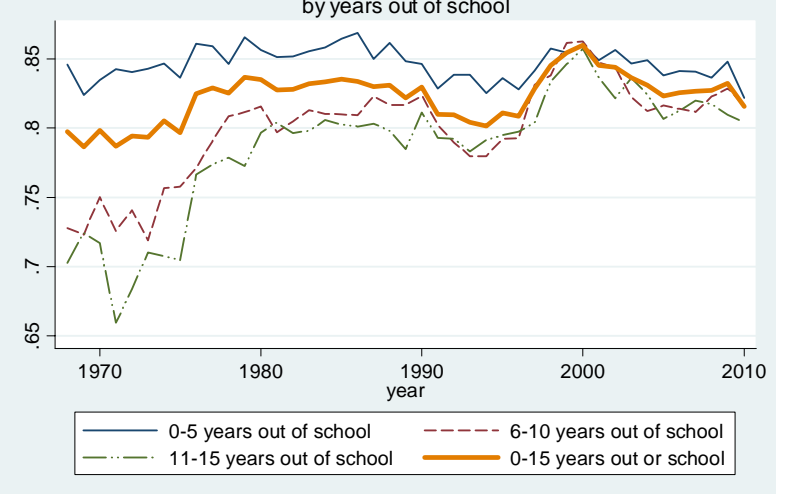

Proportion of Unmarried Women in the Labor Force

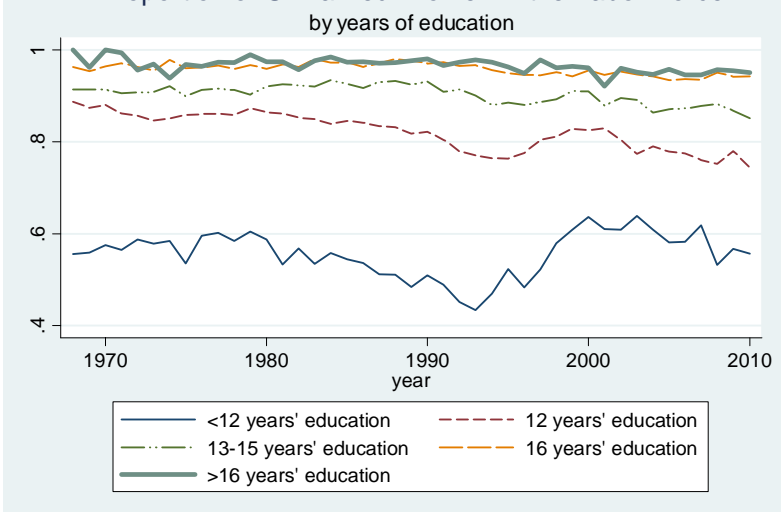




\section{Figure 5: Labor Force Participation and Hours Worked by All Women}
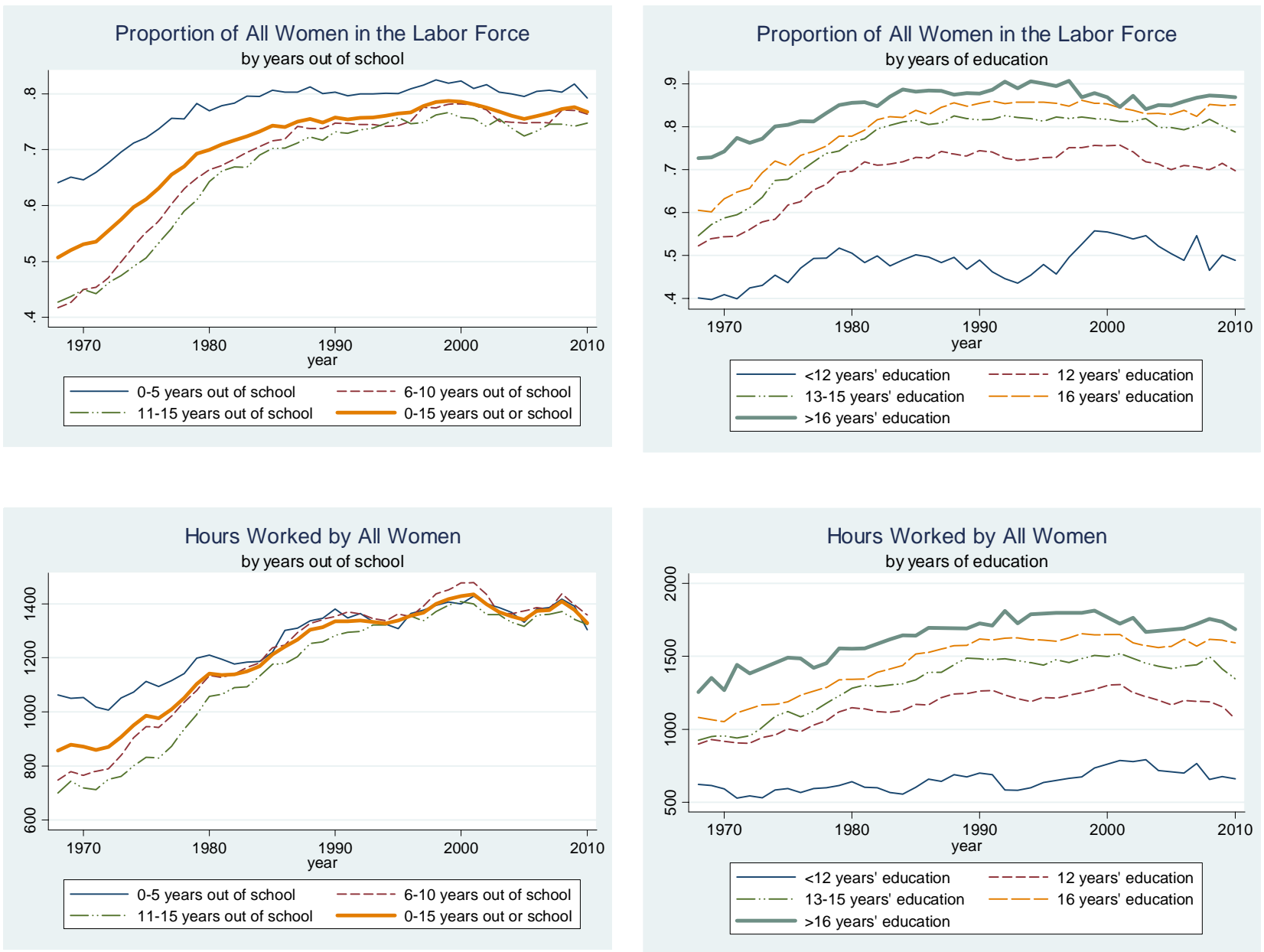
Figure 6: Age Group and Cohort Sex Ratios ${ }^{7}$
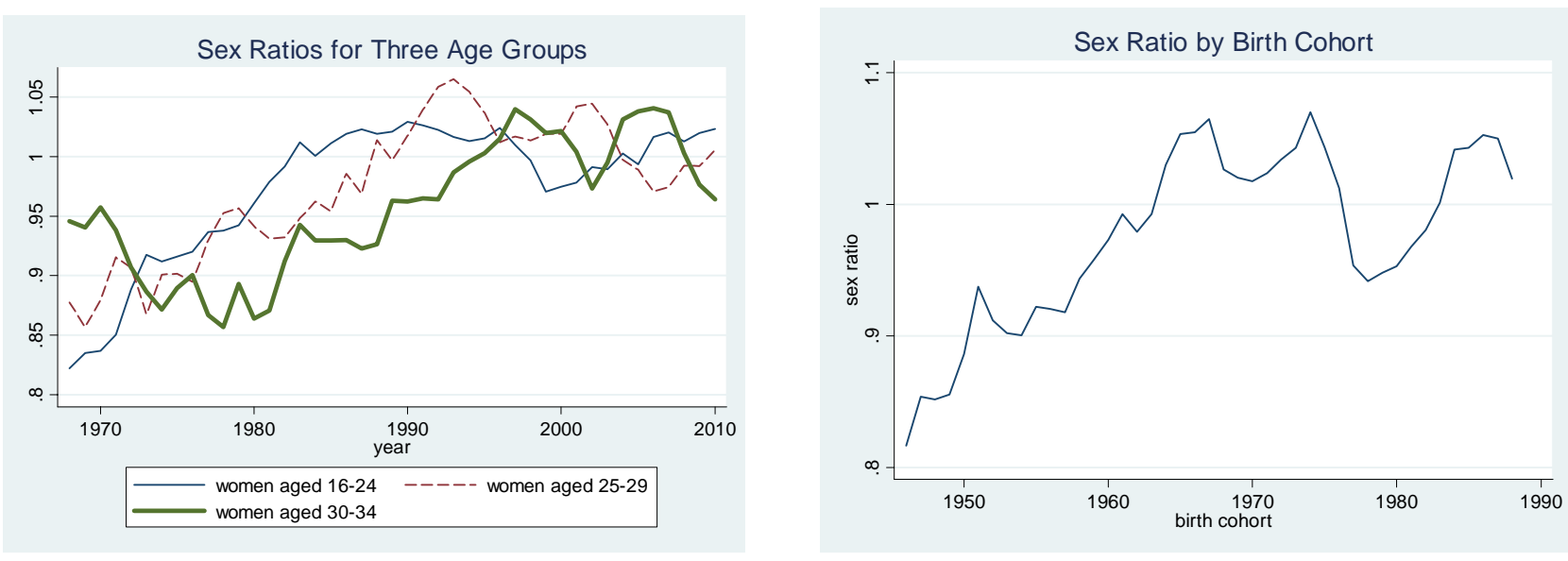

\footnotetext{
${ }^{7}$ The age group sex ratio is calculated to vary over a woman's lifetime, because of her exposure to different ratios throughout her life through the risk of divorce. The cohort ratio represents the ratio a woman experienced when she was 20-24, and is held constant for her throughout her life.
} 


\begin{tabular}{|c|c|c|c|c|c|c|c|c|}
\hline \multirow[b]{3}{*}{ \# of Observations } & \multicolumn{4}{|c|}{$\begin{array}{l}\text { Annual Hours Worked (including zeroes) } \\
\text { by Years Out of School }\end{array}$} & \multicolumn{4}{|c|}{$\begin{array}{c}\text { Labor Force Participation } \\
\text { by Years Out of School }\end{array}$} \\
\hline & $0-15$ & $0-5$ & $6-10$ & $11-15$ & $0-15$ & $0-5$ & $6-10$ & $11-15$ \\
\hline & 507467 & 186829 & 170016 & 150622 & 507467 & 186829 & 170016 & 150622 \\
\hline Adjusted R-Square & 0.1786 & 0.2209 & 0.1941 & 0.1433 & 0.1273 & 0.1606 & 0.1338 & 0.0893 \\
\hline Log older family income & $\begin{array}{c}117.64 \\
(16.1)\end{array}$ & $\begin{array}{l}139.13 \\
(11.4)\end{array}$ & $\begin{array}{c}107.59 \\
(8.8)\end{array}$ & $\begin{array}{c}94.32 \\
(7.2)\end{array}$ & $\begin{array}{c}0.05 \\
(13.9)\end{array}$ & $\begin{array}{l}0.06 \\
(9.3)\end{array}$ & $\begin{array}{l}0.05 \\
(7.5)\end{array}$ & $\begin{array}{l}0.04 \\
(6.1)\end{array}$ \\
\hline Age/Time-varying sex ratio & $\begin{array}{l}169.70 \\
(13.0)\end{array}$ & $\begin{array}{c}194.35 \\
(8.9)\end{array}$ & $\begin{array}{c}199.70 \\
(9.5)\end{array}$ & $\begin{array}{c}134.91 \\
(5.3)\end{array}$ & $\begin{array}{c}0.09 \\
(13.0)\end{array}$ & $\begin{array}{l}0.11 \\
(9.5)\end{array}$ & $\begin{array}{l}0.09 \\
(8.0)\end{array}$ & $\begin{array}{l}0.07 \\
(5.9)\end{array}$ \\
\hline Logged own wage & $\begin{array}{l}540.04 \\
(87.2)\end{array}$ & $\begin{array}{c}337.64 \\
(42.1)\end{array}$ & $\begin{array}{l}761.36 \\
(62.8)\end{array}$ & $\begin{array}{l}778.75 \\
(45.1)\end{array}$ & $\begin{array}{c}0.25 \\
(69.6)\end{array}$ & $\begin{array}{c}0.16 \\
(34.8)\end{array}$ & $\begin{array}{c}0.33 \\
(46.7)\end{array}$ & $\begin{array}{c}0.34 \\
(37.4)\end{array}$ \\
\hline Time* Own wage & $\begin{array}{c}-6.22 \\
(-28.6)\end{array}$ & $\begin{array}{c}-3.78 \\
(-11.8)\end{array}$ & $\begin{array}{l}-10.87 \\
(-25.8)\end{array}$ & $\begin{array}{l}-11.64 \\
(-20.7)\end{array}$ & $\begin{array}{c}-0.0027- \\
(-22.2)\end{array}$ & $\begin{array}{c}-0.0013 \\
(-6.7)\end{array}$ & $\begin{array}{l}-0.0043 \\
(-17.4)\end{array}$ & $\begin{array}{l}-0.0055 \\
(-18.6)\end{array}$ \\
\hline Logged male wage & $\begin{array}{c}-18.26 \\
(-4.6)\end{array}$ & $\begin{array}{l}-21.09 \\
(-3.5)\end{array}$ & $\begin{array}{l}-15.47 \\
(-2.2)\end{array}$ & $\begin{array}{l}-30.74 \\
(-3.9)\end{array}$ & $\begin{array}{l}-0.01 \\
(-7.2)\end{array}$ & $\begin{array}{c}-0.005 \\
(-1.5)\end{array}$ & $\begin{array}{l}-0.01 \\
(-3.4)\end{array}$ & $\begin{array}{l}-0.02 \\
(-4.2)\end{array}$ \\
\hline Married? & $\begin{array}{l}-391.11 \\
(-138.4)\end{array}$ & $\begin{array}{l}-329.26 \\
(-75.4)\end{array}$ & $\begin{array}{l}-419.06 \\
(-85.6)\end{array}$ & $\begin{array}{l}-424.21 \\
(-75.1)\end{array}$ & $\begin{array}{c}-0.20 \\
(-136.5)\end{array}$ & $\begin{array}{c}-0.23 \\
(-98.8)\end{array}$ & $\begin{array}{c}-0.20 \\
(-76.3)\end{array}$ & $\begin{array}{c}-0.16 \\
(-57.3)\end{array}$ \\
\hline Time Trend & $\begin{array}{l}18.05 \\
(31.9)\end{array}$ & $\begin{array}{l}10.45 \\
(13.1)\end{array}$ & $\begin{array}{l}31.79 \\
(28.4)\end{array}$ & $\begin{array}{l}33.29 \\
(21.7)\end{array}$ & $\begin{array}{c}0.01 \\
(22.9)\end{array}$ & $\begin{array}{l}0.002 \\
(5.1)\end{array}$ & $\begin{array}{c}0.01 \\
(19.5)\end{array}$ & $\begin{array}{c}0.01 \\
(18.5)\end{array}$ \\
\hline Years of education: $<12$ ? & $\begin{array}{l}-592.79 \\
(-71.8)\end{array}$ & $\begin{array}{l}-822.96 \\
(-66.9)\end{array}$ & $\begin{array}{l}-470.44 \\
(-32.1)\end{array}$ & $\begin{array}{l}-340.59 \\
(-20.2)\end{array}$ & $\begin{array}{c}-0.23 \\
(-47.2)\end{array}$ & $\begin{array}{c}-0.33 \\
(-41.5)\end{array}$ & $\begin{array}{c}-0.18 \\
(-20.8)\end{array}$ & $\begin{array}{c}-0.14 \\
(-15.9)\end{array}$ \\
\hline 12 years? & $\begin{array}{c}-159.14 \\
(-29.0)\end{array}$ & $\begin{array}{l}-306.73 \\
(-36.4)\end{array}$ & $\begin{array}{l}-98.11 \\
(-10.3)\end{array}$ & $\begin{array}{l}-2.35 \\
(-0.2)\end{array}$ & $\begin{array}{c}-0.05 \\
(-18.1)\end{array}$ & $\begin{array}{c}-0.12 \\
(-26.2)\end{array}$ & $\begin{array}{l}-0.02 \\
(-3.7)\end{array}$ & $\begin{array}{l}0.004 \\
(0.8)\end{array}$ \\
\hline 13-15 years? & $\begin{array}{l}-23.26 \\
(-4.9)\end{array}$ & $\begin{array}{l}-117.13 \\
(-16.2)\end{array}$ & $\begin{array}{l}-2.25 \\
(-0.3)\end{array}$ & $\begin{array}{c}84.51 \\
(9.1)\end{array}$ & $\begin{array}{l}0.01 \\
(2.5)\end{array}$ & $\begin{array}{c}-0.05 \\
(-10.8)\end{array}$ & $\begin{array}{l}0.03 \\
(5.8)\end{array}$ & $\begin{array}{l}0.04 \\
(9.6)\end{array}$ \\
\hline$>16$ years? & $\begin{array}{l}44.69 \\
(6.9)\end{array}$ & $\begin{array}{l}21.77 \\
(2.0)\end{array}$ & $\begin{array}{c}45.02 \\
(4.2)\end{array}$ & $\begin{array}{c}92.75 \\
(7.8)\end{array}$ & $\begin{array}{l}0.01 \\
(3.4)\end{array}$ & $\begin{array}{l}-0.02 \\
(-3.6)\end{array}$ & $\begin{array}{l}0.02 \\
(4.0)\end{array}$ & $\begin{array}{l}0.04 \\
(6.5)\end{array}$ \\
\hline African American? & $\begin{array}{l}-76.27 \\
(-12.1)\end{array}$ & $\begin{array}{c}-209.77 \\
(-21.3)\end{array}$ & $\begin{array}{c}-34.79 \\
(-3.2)\end{array}$ & $\begin{array}{c}58.45 \\
(4.9)\end{array}$ & $\begin{array}{l}-0.01 \\
(-3.9)\end{array}$ & $\begin{array}{c}-0.06 \\
(-12.3)\end{array}$ & $\begin{array}{l}0.01 \\
(2.3)\end{array}$ & $\begin{array}{l}0.04 \\
(6.4)\end{array}$ \\
\hline Other non-white races? & $\begin{array}{c}-65.75 \\
(-6.5) \\
\end{array}$ & $\begin{array}{c}-135.51 \\
(-8.2) \\
\end{array}$ & $\begin{array}{c}-64.62 \\
(-3.8) \\
\end{array}$ & $\begin{array}{c}27.80 \\
(1.5) \\
\end{array}$ & $\begin{array}{r}-0.04 \\
(-8.4)\end{array}$ & $\begin{array}{l}-0.08 \\
(-8.9)\end{array}$ & $\begin{array}{l}-0.05 \\
(-5.4)\end{array}$ & $\begin{array}{c}0.00 \\
(-0.3)\end{array}$ \\
\hline
\end{tabular}




\begin{tabular}{|c|c|c|c|c|c|c|c|c|}
\hline \multirow[b]{3}{*}{ \# of Observations } & \multicolumn{4}{|c|}{$\begin{array}{l}\text { Annual Hours Worked (including zeroes) } \\
\text { by years out of school }\end{array}$} & \multicolumn{4}{|c|}{$\begin{array}{l}\text { Labor Force Participation } \\
\text { by years out of school }\end{array}$} \\
\hline & $0-15$ & $0-5$ & $6-10$ & $11-15$ & $0-15$ & $0-5$ & $6-10$ & $11-15$ \\
\hline & 302093 & 79605 & 111913 & 110575 & 302093 & 79605 & 111913 & 110575 \\
\hline Adj R-Square & 0.154 & 0.2016 & 0.1648 & 0.1311 & 0.0988 & 0.1169 & 0.1077 & 0.0836 \\
\hline Logged older family income & $\begin{array}{r}101.66 \\
(11.8)\end{array}$ & $\begin{array}{r}96.41 \\
(5.5)\end{array}$ & $\begin{array}{c}108.07 \\
(7.8)\end{array}$ & $\begin{array}{c}87.52 \\
(6.3)\end{array}$ & $\begin{array}{l}0.05 \\
(9.7)\end{array}$ & $\begin{array}{l}0.04 \\
(3.9)\end{array}$ & $\begin{array}{l}0.05 \\
(7.0)\end{array}$ & $\begin{array}{l}0.04 \\
(4.8)\end{array}$ \\
\hline Age/Time-varying sex ratio & $\begin{array}{c}134.72 \\
(7.9)\end{array}$ & $\begin{array}{c}220.50 \\
(6.2)\end{array}$ & $\begin{array}{c}166.38 \\
(6.4)\end{array}$ & $\begin{array}{l}87.52 \\
(3.0)\end{array}$ & $\begin{array}{l}0.09 \\
(9.3)\end{array}$ & $\begin{array}{l}0.17 \\
(8.3)\end{array}$ & $\begin{array}{l}0.08 \\
(5.7)\end{array}$ & $\begin{array}{l}0.06 \\
(3.8)\end{array}$ \\
\hline Own log wage & $\begin{array}{l}724.44 \\
(85.0)\end{array}$ & $\begin{array}{l}555.34 \\
(43.8)\end{array}$ & $\begin{array}{c}804.23 \\
(54.4)\end{array}$ & $\begin{array}{l}740.33 \\
(36.2)\end{array}$ & $\begin{array}{c}0.35 \\
(66.5)\end{array}$ & $\begin{array}{c}0.28 \\
(34.2)\end{array}$ & $\begin{array}{c}0.39 \\
(41.8)\end{array}$ & $\begin{array}{c}0.35 \\
(30.8)\end{array}$ \\
\hline Time*Own log wage & $\begin{array}{c}-8.86 \\
(-29.4)\end{array}$ & $\begin{array}{c}-5.56 \\
(-10.2)\end{array}$ & $\begin{array}{l}-10.06 \\
(-19.1)\end{array}$ & $\begin{array}{c}-8.86 \\
(-13.3)\end{array}$ & $\begin{array}{c}-0.0045 \\
(-24.7)\end{array}$ & $\begin{array}{c}-0.0026 \\
(-7.5)\end{array}$ & $\begin{array}{c}-0.0047 \\
(-14.4)\end{array}$ & $\begin{array}{r}-0.0047 \\
(-13.0)\end{array}$ \\
\hline Husband's log wage & $\begin{array}{c}-233.78 \\
(-55.4)\end{array}$ & $\begin{array}{c}-148.86 \\
(-18.4)\end{array}$ & $\begin{array}{l}-220.27 \\
(-31.9)\end{array}$ & $\begin{array}{c}-274.78 \\
(-39.1)\end{array}$ & $\begin{array}{c}-0.11 \\
(-48.0)\end{array}$ & $\begin{array}{c}-0.09 \\
(-19.5)\end{array}$ & $\begin{array}{c}-0.11 \\
(-28.2)\end{array}$ & $\begin{array}{c}-0.12 \\
(-31.9)\end{array}$ \\
\hline African American? & $\begin{array}{c}117.64 \\
(5.5)\end{array}$ & $\begin{array}{l}10.21 \\
(0.3)\end{array}$ & $\begin{array}{c}105.00 \\
(3.2)\end{array}$ & $\begin{array}{c}207.96 \\
(5.7)\end{array}$ & $\begin{array}{l}0.07 \\
(6.0)\end{array}$ & $\begin{array}{l}0.04 \\
(1.7)\end{array}$ & $\begin{array}{l}0.06 \\
(3.4)\end{array}$ & $\begin{array}{l}0.09 \\
(5.3)\end{array}$ \\
\hline Other non-white races? & $\begin{array}{l}-23.90 \\
(-1.5)\end{array}$ & $\begin{array}{c}-215.17 \\
(-6.6)\end{array}$ & $\begin{array}{c}-14.53 \\
(-0.6)\end{array}$ & $\begin{array}{l}57.61 \\
(2.2)\end{array}$ & $\begin{array}{l}-0.03 \\
(-4.0)\end{array}$ & $\begin{array}{l}-0.11 \\
(-6.1)\end{array}$ & $\begin{array}{l}-0.03 \\
(-2.1)\end{array}$ & $\begin{array}{l}-0.002 \\
(-0.2)\end{array}$ \\
\hline Time Trend & $\begin{array}{l}27.16 \\
(34.2)\end{array}$ & $\begin{array}{l}16.99 \\
(12.3)\end{array}$ & $\begin{array}{l}32.16 \\
(23.2)\end{array}$ & $\begin{array}{l}26.76 \\
(14.7)\end{array}$ & $\begin{array}{c}0.01 \\
(27.5)\end{array}$ & $\begin{array}{l}0.01 \\
(9.1)\end{array}$ & $\begin{array}{c}0.01 \\
(16.9)\end{array}$ & $\begin{array}{c}0.01 \\
(13.1)\end{array}$ \\
\hline Years of education: $<12$ ? & $\begin{array}{c}-438.93 \\
(-41.1)\end{array}$ & $\begin{array}{c}-630.31 \\
(-32.5)\end{array}$ & $\begin{array}{c}-352.83 \\
(-20.1)\end{array}$ & $\begin{array}{c}-378.16 \\
(-20.2)\end{array}$ & $\begin{array}{c}-0.21 \\
(-33.7)\end{array}$ & $\begin{array}{c}-0.30 \\
(-24.6)\end{array}$ & $\begin{array}{c}-0.16 \\
(-15.5)\end{array}$ & $\begin{array}{c}-0.20 \\
(-19.2)\end{array}$ \\
\hline 12 years? & $\begin{array}{c}-139.52 \\
(-19.0)\end{array}$ & $\begin{array}{c}-269.60 \\
(-19.3)\end{array}$ & $\begin{array}{l}-90.07 \\
(-7.5)\end{array}$ & $\begin{array}{l}-81.81 \\
(-6.7)\end{array}$ & $\begin{array}{c}-0.07 \\
(-18.4)\end{array}$ & $\begin{array}{c}-0.15 \\
(-17.7)\end{array}$ & $\begin{array}{l}-0.05 \\
(-6.9)\end{array}$ & $\begin{array}{l}-0.05 \\
(-7.8)\end{array}$ \\
\hline 13 - 15 years? & $\begin{array}{l}-41.39 \\
(-6.6)\end{array}$ & $\begin{array}{c}-129.03 \\
(-10.7)\end{array}$ & $\begin{array}{l}-26.87 \\
(-2.6)\end{array}$ & $\begin{array}{l}18.79 \\
(1.8)\end{array}$ & $\begin{array}{l}-0.02 \\
(-5.3)\end{array}$ & $\begin{array}{l}-0.07 \\
(-9.9)\end{array}$ & $\begin{array}{c}-0.003 \\
(-0.4)\end{array}$ & $\begin{array}{c}0.003 \\
(0.5)\end{array}$ \\
\hline >16 years? & $\begin{array}{c}133.18 \\
(16.5)\end{array}$ & $\begin{array}{c}103.13 \\
(6.4)\end{array}$ & $\begin{array}{c}118.73 \\
(9.2)\end{array}$ & $\begin{array}{l}169.54 \\
(12.7)\end{array}$ & $\begin{array}{c}0.06 \\
(14.4)\end{array}$ & $\begin{array}{l}0.04 \\
(3.7)\end{array}$ & $\begin{array}{l}0.06 \\
(8.6)\end{array}$ & $\begin{array}{c}0.08 \\
(11.8)\end{array}$ \\
\hline Husband African American? & $\begin{array}{c}89.26 \\
(4.4)\end{array}$ & $\begin{array}{l}15.37 \\
(0.4)\end{array}$ & $\begin{array}{c}124.05 \\
(4.0)\end{array}$ & $\begin{array}{l}89.88 \\
(2.5)\end{array}$ & $\begin{array}{l}0.04 \\
(4.1)\end{array}$ & $\begin{array}{l}0.02 \\
(0.9)\end{array}$ & $\begin{array}{l}0.07 \\
(3.8)\end{array}$ & $\begin{array}{l}0.04 \\
(2.0)\end{array}$ \\
\hline Husband Other non-white? & $\begin{array}{l}-51.86 \\
(-3.4)\end{array}$ & $\begin{array}{c}-108.97 \\
(-3.6)\end{array}$ & $\begin{array}{l}-71.32 \\
(-3.0)\end{array}$ & $\begin{array}{l}-2.83 \\
(-0.1)\end{array}$ & $\begin{array}{l}-0.03 \\
(-3.7)\end{array}$ & $\begin{array}{l}-0.06 \\
(-3.4)\end{array}$ & $\begin{array}{l}-0.04 \\
(-3.1)\end{array}$ & $\begin{array}{l}-0.01 \\
(-0.4)\end{array}$ \\
\hline Husband Yrs.Educ: <12? & $\begin{array}{c}-35.94 \\
(-4.3)\end{array}$ & $\begin{array}{c}-142.11 \\
(-9.4)\end{array}$ & $\begin{array}{c}-52.26 \\
(-3.8)\end{array}$ & $\begin{array}{l}64.15 \\
(4.3)\end{array}$ & $\begin{array}{l}0.00 \\
(0.6)\end{array}$ & $\begin{array}{l}-0.02 \\
(-2.3)\end{array}$ & $\begin{array}{c}-0.002 \\
(-0.3)\end{array}$ & $\begin{array}{l}0.03 \\
(3.5)\end{array}$ \\
\hline Husband 12 years? & $\begin{array}{l}75.43 \\
(12.2)\end{array}$ & $\begin{array}{l}-27.85 \\
(-2.3)\end{array}$ & $\begin{array}{c}57.95 \\
(5.8)\end{array}$ & $\begin{array}{c}164.85 \\
(16.0)\end{array}$ & $\begin{array}{c}0.05 \\
(15.4)\end{array}$ & $\begin{array}{l}0.02 \\
(3.5)\end{array}$ & $\begin{array}{l}0.05 \\
(8.4)\end{array}$ & $\begin{array}{c}0.07 \\
(14.2)\end{array}$ \\
\hline Husband $13-15$ years? & $\begin{array}{l}95.45 \\
(15.7)\end{array}$ & $\begin{array}{c}28.87 \\
(2.5)\end{array}$ & $\begin{array}{c}72.40 \\
(7.4)\end{array}$ & $\begin{array}{c}159.82 \\
(15.8)\end{array}$ & $\begin{array}{c}0.06 \\
(18.0)\end{array}$ & $\begin{array}{l}0.05 \\
(6.4)\end{array}$ & $\begin{array}{l}0.05 \\
(8.5)\end{array}$ & $\begin{array}{c}0.08 \\
(15.5)\end{array}$ \\
\hline Husband $>16$ years? & $\begin{array}{r}-148.20 \\
(-19.4) \\
\end{array}$ & $\begin{array}{c}-148.34 \\
(-9.5) \\
\end{array}$ & $\begin{array}{c}-146.39 \\
(-12.0)\end{array}$ & $\begin{array}{c}-121.59 \\
(-9.9) \\
\end{array}$ & $\begin{array}{c}-0.08 \\
(-18.8) \\
\end{array}$ & $\begin{array}{l}-0.08 \\
(-8.3) \\
\end{array}$ & $\begin{array}{c}-0.08 \\
(-12.4) \\
\end{array}$ & $\begin{array}{c}-0.06 \\
(-10.2) \\
\end{array}$ \\
\hline
\end{tabular}




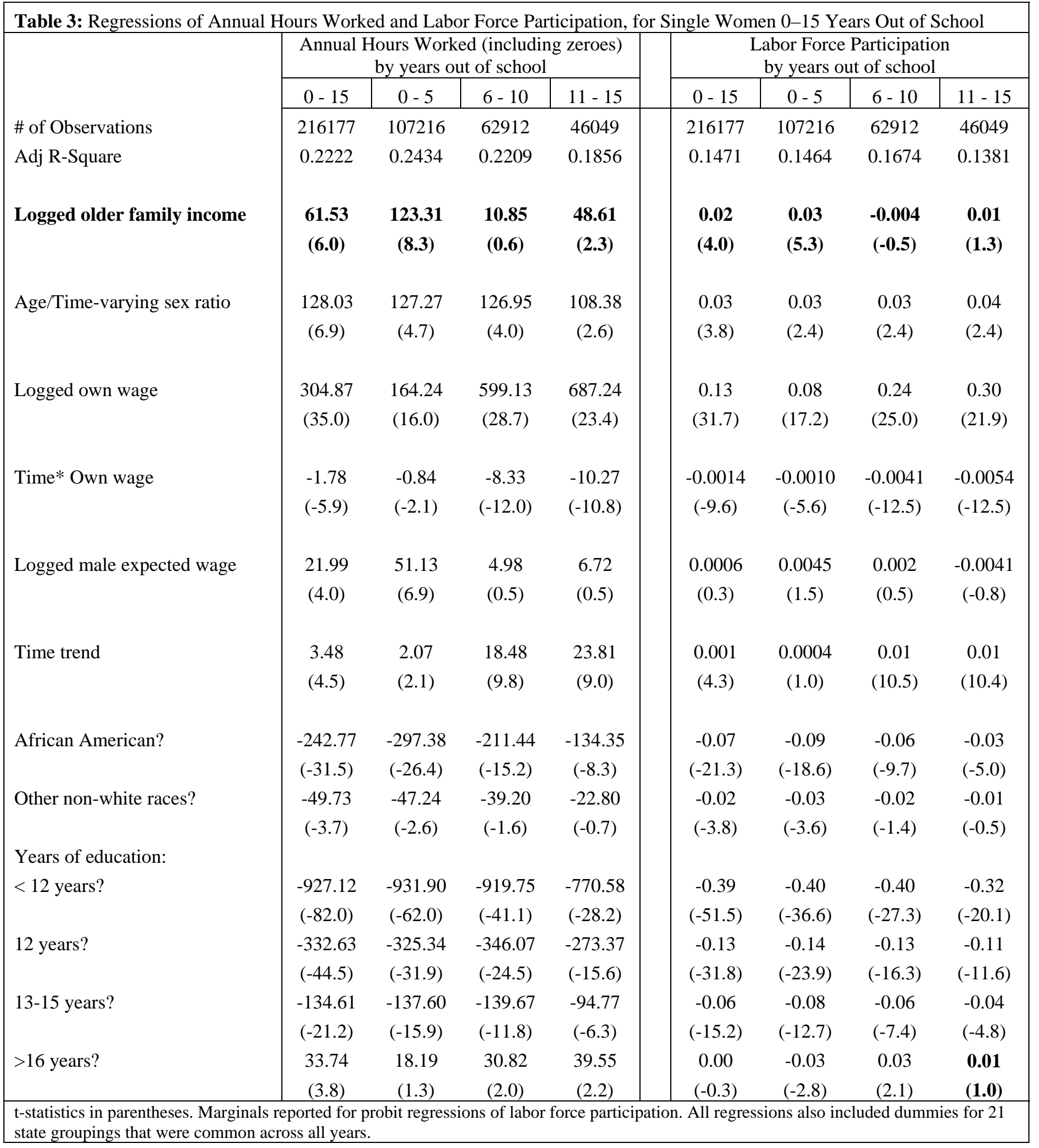




\begin{tabular}{|c|c|c|}
\hline \multicolumn{3}{|c|}{$\begin{array}{l}\text { Table 4: Robust Results for Women's Starting } \\
\text { Wage Regressed on a Relative Cohort Size } \\
\text { Variable }\end{array}$} \\
\hline & $\begin{array}{l}\text { Starting } \\
\text { wage }\end{array}$ & $\begin{array}{c}\text { Relative } \\
\text { starting } \\
\text { wage }\end{array}$ \\
\hline Number of Obs & 16,617 & 8,074 \\
\hline R-Square & 0.2887 & 0.1392 \\
\hline 25-year lagged GFR & $\begin{array}{l}-0.031 \\
(-14.2)\end{array}$ & $\begin{array}{c}-0.0024 \\
(-16.2)\end{array}$ \\
\hline Time & $\begin{array}{r}-0.032 \\
(-8.3)\end{array}$ & $\begin{array}{c}-0.0017 \\
(-6.7)\end{array}$ \\
\hline African American? & $\begin{array}{r}-0.059 \\
(-0.6)\end{array}$ & $\begin{array}{l}0.1412 \\
(17.7)\end{array}$ \\
\hline Other non-white races? & $\begin{array}{r}0.852 \\
(4.1)\end{array}$ & $\begin{array}{c}0.1763 \\
(8.1)\end{array}$ \\
\hline \multicolumn{3}{|l|}{ Level of education: } \\
\hline$<8$ years? & $\begin{array}{r}-1.296 \\
(-2.5)\end{array}$ & $\begin{array}{c}0.1554 \\
(2.7)\end{array}$ \\
\hline 8-11 years? & $\begin{array}{l}-1.037 \\
(-13.9)\end{array}$ & $\begin{array}{c}0.0473 \\
(8.8)\end{array}$ \\
\hline 13-15 years? & $\begin{array}{r}0.957 \\
(12.3)\end{array}$ & $\begin{array}{c}-0.0268 \\
(-5.9)\end{array}$ \\
\hline 16 years? & $\begin{array}{r}4.871 \\
(38.9)\end{array}$ & $\begin{array}{c}-0.0005 \\
(-0.1)\end{array}$ \\
\hline$>16$ years? & $\begin{array}{r}9.970 \\
(34.8)\end{array}$ & $\begin{array}{c}0.0707 \\
(7.5)\end{array}$ \\
\hline \multicolumn{3}{|c|}{$\begin{array}{l}\text { t-statistics in parentheses. Both regressions also } \\
\text { included dummies for } 21 \text { state groupings that were } \\
\text { common over all years. The relative starting wage is the } \\
\text { starting wage divided by the average wage of men with } \\
\text { 25-34 years of work experience. The number of } \\
\text { observations is less because of cells where one or the } \\
\text { other was missing. }\end{array}$} \\
\hline
\end{tabular}




\section{$\underline{\text { Data Appendix }}$}

The data used in these analyses were taken from the annual March Current Population Survey (CPS) as compiled by Unicon Corporation in "CPS Utilities". Data for 1968-2010 were used, except for older family income, where data were for 1966-2010. Earlier years are less consistent in the CPS.

For the graphs, as well as in the analyses, March Supplement Weights were used. Labor force participation was identified using the CPS employment status recode (except for 1994 where the mlr code was used, since the esr is set to zero for all records in that year). Annual wages were calculated as income from wages and salary divided by annual hours, which in turn was calculated as weeks worked in the year times usual hours worked per week. In years prior to 1976, where hours and weeks were reported only categorically, an algorithm developed by Welch (1979) was used to identify hours and weeks worked.

Data cover only women in their first fifteen years out of school, and include married men with spouse present aged 16-54, if their wives were in their first fifteen years out of school. Single women in the analyses include married women with spouse absent, and divorced, separated, widowed, and nevermarried women. Husbands and wives were matched using the hierarchical structure of the CPS data files, since it was determined that not all records are unique for matching based on the available family variables ${ }^{8}$.

Those with allocated hours or weeks worked were dropped from the data. In addition, persons in the military have been excluded, and those who are retired or in school were specifically excluded as well.

The March Supplement Weights were used in all analyses, and in order to ensure that each year was given equal weight, the weights were divided by the sum of weights in each year to make them sum to one in each year. Because the method of reporting educational attainment was changed beginning in 1993, Jaeger's (1997) correspondence method was used to determine the highest grade completed after that date.

All dollar figures are expressed in constant 2009 dollars. As in Blau and Kahn (2007), and Macunovich (2010), top-coded wages were multiplied by a factor of 1.45. Topcodes were applied to all years in which the highest dollar figure exceeded the lowest topcode imposed over the years by the CPS, in 2009 dollars. That is, the topcode was made uniform over all years. For annual wages, this was \$50,000 in 1981 dollars.

Following Blau and Kahn, and Macunovich, wages were imputed for those who were self-employed, those who reported no income, and those whose hourly wage was calculated as falling outside the range of $\$ 2.50$ - \$250 in 2008 dollars. The imputation process was based on regressions of reported valid wages. For those reporting less than 20 weeks worked, imputed wages were based on a regression using those with a valid wage who worked less than 20 weeks. For those reporting 20 or more weeks worked, imputed wages were based on a regression using those with a valid wage who reported 20 or more weeks worked. This process was carried out separately for married women with spouse present, single women, and husbands with a spouse present. The regressors used were age, age squared, five education categories (less than 12 years, 12 years,13-15 years, 16 years, and 17+ years), four race categories (white, black, Hispanic and other), eight region dummies and metropolitan area indicators (central city, other MSA and non-MSA). The regressions were performed on five-year groupings to allow for changes over time in characteristics determining wages.

Older family income in 2009 dollars was calculated for families with head of either sex aged 45-54, using the same uniform topcoding procedure applied to wage income. This was \$50,000 in 1975 dollars. March Family Weights were used throughout. Older family income was applied to individual records by

\footnotetext{
${ }^{8}$ This was confirmed by Greg Weyland at the Census Bureau, and Eanswythe Grabowski at Unicon, in communications dated September 22, 2009.
} 
matching at the year-state-race-education level. Non-uniform states were used over the years in order to achieve the highest possible level of matching.

The female starting wage in 2009 dollars was calculated using annual earnings divided by hours worked (again using the Welch (1979) algorithm for years prior to 1976, for women in their first year out of school. March Supplement Weights were used. The same topcoding procedure was used, as outlined above for the wage imputation process in working with individual wages.

For single women, the male wage used in 2009 dollars was the average male wage (the hourly wage calculated as above) in specific year-state-race-education specific groupings, matched with women two years younger. This average wage was used in an expected form - that is, the observed wage multiplied by the employment rate (1 - the unemployment rate) specific to the year-state-race-education-experience group. March Supplement Weights were used.

All dollar figures in the regressions were used in logged form.

Experience is measured as years out of school, using age-6-years of education. For individuals with less than ten years of schooling, this was calculated as age-16. The state groupings differ over the period, with 30 groups in the 1968-72 period, 23 in the 1973-76 period, and 51 from 1977 onward (including the District of Columbia). In all regressions, dummies for the 21 groups which have been common over all years, are included, together with dummies for years out of school. 